\title{
Clinical copper metabolism parameters in patients with retinitis pigmentosa and other tapeto-retinal degenerations
}

\author{
NIELS EHLERS AND NIELS BÜLOW \\ From the Department of Ophthalmology, Arhus Kommunehospital, Arhus, Denmark
}

SUMMARY Reports have appeared of abnormal copper metabolism in retinitis pigmentosa, and of a family with vitelliform retinal degeneration in which other members suffered from hepatolenticular degeneration. In the present study 15 patients with retinitis pigmentosa, 4 with various other retinal degenerations, and 1 with a family disposition to retinitis pigmentosa were examined. The copper concentration in serum and the coeruloplasmin concentration in plasma were found to be within normal limits. In 9 of the patients with retinitis pigmentosa the urinary excretion of copper per 24 hours was determined and was found to be normal. The results of the present study lend no support to the hypothesis of abnormal copper metabolism in retinitis pigmentosa.

In view of their findings in patients with retinitis pigmentosa of normal serum copper concentration, reduced plasma coeruloplasmin concentration, and increased urinary excretion of copper Gahlot et al. (1976) suggested that retinitis pigmentosa might be caused by a disorder of copper metabolism. We found it worthwhile to perform a similar study, as we were already engaged in metabolic studies of pigmentary retinopathies (Ehlers and Schønheyder, 1977), and because Brink (1974) had reported a family with vitelliform retinal degeneration in which several other members suffered from Wilson's hepatolenticular degeneration, well known as a disorder of copper metabolism.

\section{Material and methods}

Twenty patients were included in this study (Table 1). In accordance with the case history and the results of ophthalmoscopy, perimetry, dark adaptation, and electroretinography the patients were classified in 2 groups. The first group (Table 1A) comprised 15 patients with retinitis pigmentosa. The second group (Table 1B) comprised 4 patients with various other retinal degenerations, and 1 patient (No. 18) who had a family disposition to retinitis pigmentosa but showed no evidence of retinal degeneration.

The copper concentration in serum and the coeruloplasmin concentration in plasma was deter-

Address for reprints: Professor N. Ehlers, Department of Ophthalmology, Århus Kommunehospital, 8000 Århus C, Denmark.

\section{Table 1 Material}

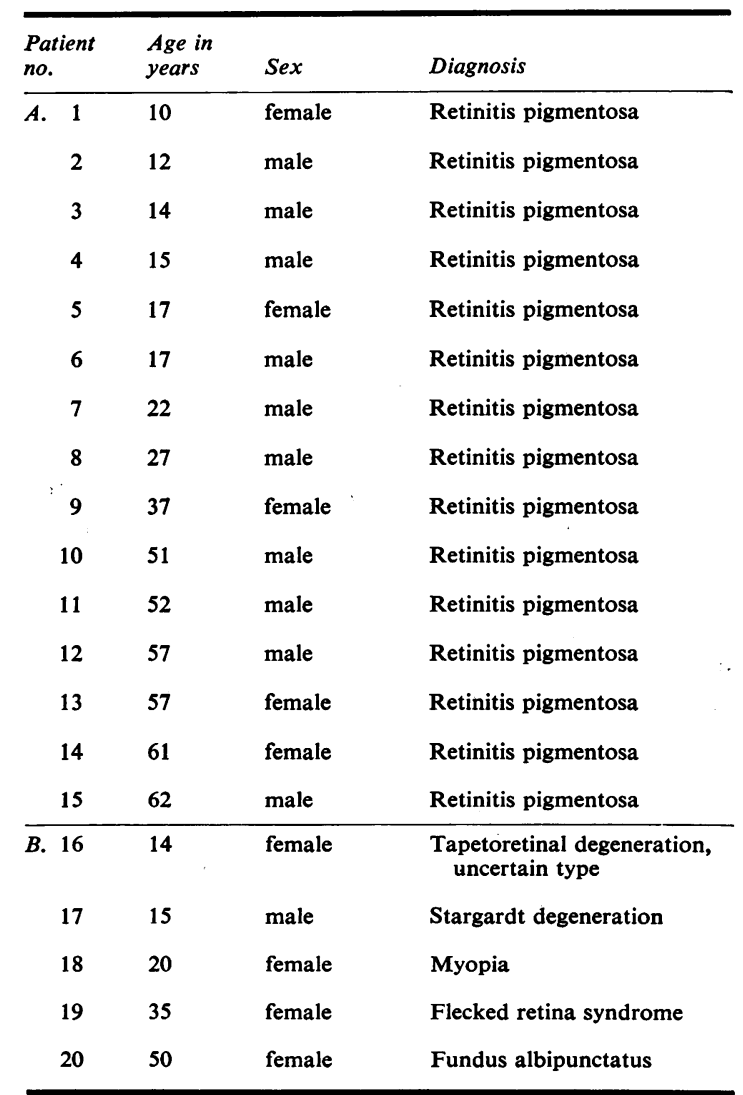


Table 2 Results

\begin{tabular}{|c|c|c|c|}
\hline $\begin{array}{l}\text { Patient } \\
\text { no. }\end{array}$ & $\begin{array}{l}\text { Copper concentration } \\
\text { in serum } \\
(\mu \mathrm{g} / 100 \mathrm{ml})\end{array}$ & $\begin{array}{l}\text { Coeruloplasmin } \\
\text { concentration } \\
\text { in plasma }(\mathrm{g} / \mathrm{l})\end{array}$ & $\begin{array}{l}\text { Copper urinary } \\
\text { excretion } \\
(\mu g / 24 \mathrm{~h})\end{array}$ \\
\hline A. 1 & 100 & 0.29 & - \\
\hline 2 & 134 & 0.41 & 25 \\
\hline 3 & 106 & $0 \cdot 30$ & 43 \\
\hline 4 & 126 & 0.44 & - \\
\hline 5 & 96 & 0.28 & - \\
\hline 6 & 130 & 0.35 & 51 \\
\hline 7 & * & $0 \cdot 24$ & 47 \\
\hline 8 & 109 & $0 \cdot 32$ & - \\
\hline 9 & 116 & 0.32 & - \\
\hline 10 & 110 & 0.31 & 68 \\
\hline 11 & 108 & $0 \cdot 37$ & 38 \\
\hline 12 & 131 & 0.34 & 47 \\
\hline 13 & 128 & $0 \cdot 35$ & 13 \\
\hline 14 & 158 & 0.57 & 60 \\
\hline 15 & 132 & 0.41 & - \\
\hline B. 16 & 122 & 0.40 & - \\
\hline 17 & 100 & $0 \cdot 27$ & - \\
\hline 18 & 101 & 0.31 & - \\
\hline 19 & 125 & $0 \cdot 32$ & - \\
\hline 20 & 106 & $0 \cdot 32$ & - \\
\hline $\begin{array}{l}\text { Normal } \\
\text { ranges } \\
( \pm 2 S D)\end{array}$ & $\begin{array}{l}\text { Male } 74 \text { to } 146 \\
\text { Female } 83 \text { to } 159\end{array}$ & 0.18 to 0.42 & 9 to 80 \\
\hline
\end{tabular}

*Sample lost in preparation

mined in all the patients by the methods described below. The urinary excretion of copper per 24 hours was determined in 9 of the patients with retinitis pigmentosa.

Copper concentration in serum was determined photometrically by the method of Jensen et al. (1964). By double determinations performed at intervals of one week the values could be reproduced with a standard deviation of $3.4 \mu \mathrm{g} / 100 \mathrm{ml}$, corresponding to about $3 \%$. Urinary excretion of copper was determined by atomic absorption. The standard deviation was $9 \mu \mathrm{g} / 1$. Coeruloplasmin concentration in plasma was determined by radial immunodiffusion by Manzini's method with a standard deviation of about $2 \cdot 5 \%$.
Results

The findings are shown in Table 2. The concentration of copper was found to be within normal limits in all the patients examined, the average value being 117.8 (SEM 3.65) $\mu \mathrm{g} / 100 \mathrm{ml}$. For coeruloplasmin all values except 2 were within the normal range. Patients 4 and 14 had raised concentrations. The average value was 0.346 (SEM 0.0164) $\mathrm{g} / \mathrm{l}$. The urinary excretion of copper per 24 hours was found to be within normal limits in all the 9 cases examined, the mean being 43.6 (SEM 5.60) $\mu \mathrm{g} / 24$ hours. It will be seen from the bottom two rows of Table 2 that even an age variation in the normal ranges of about $10-12 \%$, as given by some authors, will not alter the findings of normal parameters.

\section{Discussion}

The disorders of copper metabolism reported by Gahlot et al. (1976) in patients with retinitis pigmentosa, namely, reduced coeruloplasmin concentration and increased urinary copper excretion, were not found in the present study. Therefore the hypothesis that retinitis pigmentosa might be caused by an inborn error of copper metabolism is not supported.

Of course it is not possible from a limited study like the present to draw definite conclusions; moreover, the diagnosis of retinitis pigmentosa applies to conditions differing with regard to heredity, age of onset, severity, rate of progression, and coincidence with other diseases. Such differences were also evident among the cases classified as retinitis pigmentosa in the present series. It should also be realised that blood levels and urinary excretion are probably not a very sensitive way of investigating copper metabolism. Therefore the observations available so far do not exclude the possibility that some cases of pigmentary retinopathy, or perhaps certain stages in the degeneration, may be related to copper toxicity or to a disorder of copper metabolism.

\section{References}

Brink, J. K. (1974). Acta ophthalmologica, 52, 609.

Ehlers, N., and Schønheyder, F. (1977). Aqueous humour amino-acids in retinitis pigmentosa. Association for Eye Research XIII meeting. Bonn. July 1977.

Gahlot, D. J., Khosla, P. K., Makashir, P. D., Vasuki, K., and Basu, N. (1976). British Journal of Ophthalmology, 60, 770 .

Jensen, K. B., Thorling, E. B., and Andersen, C. J. (1964). Scandinavian Journal of Haematology, 1, 63. 